\title{
IMPRENSA OPERÁRIA: EXPRESSÃO DAS CONDIÇÕES DA MULHER E DOS MOVIMENTOS SOCIAIS URBANOS
}

\author{
Vania Regina Boschetti* \\ Valdelice Borghi Ferreira** $^{* *}$ \\ Universidade de Sorocaba
}

\begin{abstract}
RESUMO
O texto estuda o movimento pela escolarização em Sorocaba nas primeiras décadas do século XX. Entender o processo desse movimento é o objetivo deste trabalho. Os movimentos sociais em Sorocaba investem em atividades sociais, educacionais e culturais. Fundamentam-se em aspirações de identidade coletiva, se apresentam com dinâmica criadora e reivindicatória revelando, de maneira impar, a ação social do indivíduo e a participação política do ser humano no que se refere à defesa da educação inspirada na teoria racional, na qualificação para o trabalho, e, posicionamentos relacionados à educação da mulher.

Palavras-chave: movimentos sociais - educação - operários

\section{LABOR PRESS: EXPRESSION OF THE WOMEN CONDITIONS AND THE URBAN SOCIAL MOVEMENT}

\begin{abstract}
The article studies the movement pro school in Sorocaba on the earlier decades of the twentieth century. To comprehend the movement's process is the article aim. The social movements in Sorocaba invest on social activities, educational activities and cultural activities. They are based on collective identity aspirations, they are shown with creative and demanding dynamics, revealing, on a particular way, the individual social deeds and the human being political participation on the defense of the education based on the rational theory, work qualification and, positions related to women's education.

Keywords: social movements - education - workers
\end{abstract}

\section{Introduzindo conceitos}

O artigo tem por pressuposto inicial o pensamento de Aristóteles (1973), enquanto caracterização da ação humana em sociedade, e o que torna possível o seu aprimoramento para entender, participar e questionar aspectos da vida social. Aponta os conceitos de Touraine (1998) sobre movimentos sociais dos trabalhadores e suas reivindicações. Analisa a industrialização na cidade de Sorocaba destacando a formação da classe operária e a participação dos imigrantes na constituição da força de trabalho. É na configuração da classe operária, de ideologia anarquista, que os movimentos sociais se desenvolverão. $\mathrm{O}$ texto dá especial destaque para a proposta educacional de Francesc Ferrer i Guardia, ao contemplar suas ideias sobre educação para os trabalhadores e para a mulher. Focaliza a atuação da imprensa nos movimentos, pela pesquisa e transcrição das publicações do Jornal O Operário, no que se refere às necessidades do operariado e conscientização sobre o papel da mulher na cidade em transformação. 
Faz um percurso teórico pelas fontes bibliográficas pertinentes à historiografia dos movimentos sociais pela educação escolar em Sorocaba, em três vertentes: analisa as situações socioeconômicas inerentes ao processo de industrialização na cidade e sua relação com a imigração européia que vem compor a força de trabalho; investiga os posicionamentos ideológicos e sociais pela escolarização no âmbito da classe trabalhadora e, apresenta manifestações contundentes sobre a função, a ética e o comportamento da mulher, sob a ótica do ideário anarquista, expressas no Jornal $O$ Operário.

Partindo de conceito gerais da filosofia e da economia, traça um breve panorama da cidade nas primeiras décadas do século $\mathrm{XX}$, por meio da trajetória de desenvolvimento fabril e sua laboriosa composição, reconhecida exclusivamente como força de trabalho que atende às urgências do sobreviver familiar e de uma economia em expansão. Considerações necessárias para melhor compreender o momento em que, trabalho, ideologias e escolarização, por interesses distintos, cruzam suas expectativas, interesses e necessidades.

\section{A cidade}

As questões da historiografia da educação, do ensino e da pedagogia, exigem do pesquisador a busca de fontes e evidências que permitam entender o pensamento dos grupos sociais, quais são os valores políticos e econômicos atuantes, de que modo se projetam na sociedade em relação à força efetiva ou de representação, e quais são as reais possibilidades de entendimento das questões sociais e educativas que os dados e referências fazem emergir.

Estudar o atendimento escolar para as classes populares em Sorocaba nas primeiras décadas do século XX envolve a análise dos interesses dos grupos políticos, da Igreja, dos comerciantes, intelectuais, sindicalistas e operários. Essa configuração representava uma inquietação social nem sempre comum em torno das questões educativas, o que pode ser entendido como manifestação de interesses distintos da burguesia e do proletariado: a primeira para fortalecer sua condição hegemônica e, a segunda, por vislumbrar as possibilidades de usufruir de um direito de ascender socialmente, atendendo ao ideal republicano de transformar a sociedade pela expansão educacional. Enquanto inculcadora de normas, princípios e valores, a instituição escolar promoveria a manutenção da ordem, a regeneração dos vícios, a solução dos problemas sociais, atingindo o tão almejado progresso. Por isso, no período em questão, os movimentos sociais pela educação na cidade ganharam intensidade e, pela ação da imprensa operária, fizeram repercutir em ideias e ideais por uma vida de acessibilidade aos direitos do cidadão.

Os movimentos sociais se fundamentavam em aspirações de identidade coletiva e se caracterizam, entre outras, pelo alcance limitado às questões vivenciadas no cotidiano dos grupos sociais. Mesmo assim, se apresentavam como atividade criadora, um vir-a-ser. Fazer essa leitura dos sujeitos envolvidos revela, de maneira impar, a ação contínua da participação política do ser humano. Empresta-se aqui, o conceito de bios politikos de Aristóteles apresentado em duas importantes obras - Política e Ética à Nicômaco enquanto caracterização da ação humana em sociedade. Com o filósofo, é correto afirmar que o sentido maior da vida do homem é a vida na polis (comunidade política), sua condição de viver como cidadão. Por ser um animal político, sua natureza (physi) o obriga a viver na cidade (polis), o que torna possível o aprimoramento da condição humana. Ultrapassa o próprio conceito do social, de animal gregário ${ }^{1}$.

A verdadeira vida humana deve almejar a organização política para uma dimensão maior daquela vivenciada nos grupos imediatos da convivência, e, restrita do convívio 
social mais simples, onde prevalecem os registros de família, de parentesco, de amizade e de camaradagem. É a partir da compreensão desses aspectos da própria natureza, que o homem começa a entender, participar e questionar aspectos da vida social. É quando sua ação adquire um estatuto eminentemente político, ao ter a noção de governo, de dominação, de liberdade, de igualdade, do que é comum, do que é direito da pessoa e do cidadão.

Para Touraine (1998), a política concebida por Aristóteles "trazia consigo um princípio de unidade da ação com experiência humana, permitindo combinar a ação racionalizadora, com a liberdade de consciência moral, sem deixar de considerar sua separação". Da aristotélica ampliada por muitos outros pensadores, se constituiu o modelo clássico de sociedade ${ }^{2}$, a partir de quatro idéias das quais se destaca:

\begin{abstract}
a sociedade produz indivíduos semelhantes mas desiguais. Ele está, portanto, em frontal oposição ao modelo que associa igualdade e diferença e sobre o qual procuro, aqui, as condições da existência. Com efeito, o que é universal é um direito geral, e até mesmo natural, como anuncia o artigo primeiro da Declaração dos Direitos do Homem e do Cidadão de 1789. (TOURAINE, 1998, p.10)
\end{abstract}

Para o autor, o modelo clássico de sociedade é que permitiu o desenvolvimento das reivindicações operárias. Nele, o ideário da Declaração não foi suficiente para impedir que com os tempos capitalistas tornassem o homo economicus mais interessante que o homo politicus, levando as sociedades a se tornarem fortemente hierarquizadas, mesmo afirmando a igualdade dos direitos civis. Como decorrência, a história mostra uma combinação um tanto estranha onde "foram facilmente combinados os direitos civis com a desigualdade de situações sociais, com uma forte dominação de classe, com a escravização ou destruição dos colonizados e com a dominação das mulheres..." (Idem, p.11).

Identificar a realidade dos movimentos sociais implica em dissecar a sua conjuntura, levando em conta articulações, dimensões locais, regionais, nacionais e internacionais dos seus fenômenos, dos atores de sua história e do jogo de forças atuantes em seu espaço. Foi esse o caminho percorrido pelas reflexões aqui colocadas que, ainda considerou a importância da organização social que deve estar presente na dinâmica dos movimentos. Por analogia, houve por bem utilizar o pensamento de Pinto (1998, p.11), quando ele se refere à ação comunitária. Diz o autor que ela, não pode ser entendida

[...] como simples estrutura formal, mas como articulação permanente, dinâmica, dos grupos de uma população, ao redor de interesses comuns, objetivos reais, mas percebidos coletivamente, que alimentam ações coordenadas e que buscam satisfazer a esses interesses coletivos.

Enquanto país colonizado, o Brasil emergiu dessas situações com características muito próprias: até o até o início do século XIX existia um país predominantemente rural com estilo de vida estabelecido pela elite dominante, marcado pelas representações sociais da aristocracia portuguesa e pelas diferentes interações sociais definidas pelo sistema escravista.

$\mathrm{O}$ Brasil republicano nas primeiras décadas do século $\mathrm{XX}$, passou por várias transformações: industrialização, exportação de mercadorias, desenvolvimento da vida urbana, o surgimento de uma mentalidade, a burguesa, que lentamente substitui o modelo anterior. O início da industrialização do Brasil atraiu os movimentos imigratórios e o país começou a vivenciar transformações políticas e econômico-sociais. A nova realidade visualizada pela elite republicana era a de desdobramento do progresso nacional: as 
cidades deveriam simbolizar o avanço cultural da sociedade, com pessoas disciplinadas, preparadas para o trabalho dentro da ordem. No caso específico, um trabalho executado, predominantemente pelos grupos imigrantes. Entretanto, a concentração deles enquanto trabalhadores e sua organização em movimentos reivindicatórios provocaram a mudança desse conceito.

Tal transformação ocorreu em virtude de circunstâncias como as constantes reclamações sobre a dura realidade encontrada pelos imigrantes nas cidades e nas fábricas. As péssimas condições de vida, de trabalho, e, a exploração do patronato, favoreceram a eclosão do movimento operário que agitou o país durante todo o período, até porque a necessidade de mão-de-obra em novas frentes de atividades, exigia que se recebesse de fora, o braço não disponível internamente.

A cidade de Sorocaba, no interior do estado de São Paulo, estava inserida nesse quadro por apresentar, ao mesmo tempo dois segmentos econômicos de exemplar importância no contexto do país: a indústria têxtil com fiações e tecelagens, e a presença da Estrada de Ferro Sorocabana como força propulsora do transporte ferroviário, fundamental à época para o comércio interno e de exportação. As indústrias têxteis e a estrada de ferro atraiam cada vez mais imigrantes, principalmente espanhóis, italianos, portugueses. Não raro porém a vinda de alemães, ingleses, suíços que se dirigiam às técnicas mais aprimoradas.

Os imigrantes com algum capital de origem aportaram à cidade e começaram seus "pequenos negócios" ligados ao comércio de algodão, à mecânica de ferrovia, à instalação de indústrias variadas, inclusive para abastecimento nacional, como o caso da produção de banha de porco enlatada, indústria de chapéus e de cervejas.

Esses imigrantes faziam parte da burguesia, juntamente com a elite da terra, e eram moradores da região nobre da cidade: a praça central e seu entorno.

Os imigrantes sem capital e sem estudo que vieram para Sorocaba eram, principalmente, italianos e espanhóis.

\section{Os movimentos sociais em Sorocaba}

Segundo dados de Oliveira (2002), pode-se considerar que os espanhóis chegaram a Sorocaba a partir de 1895, intensificando o fluxo nas primeiras décadas do século XX. Provinham, em sua maioria, da região de Andaluzia (Províncias de Huelva, Sevilha, Cádiz, Córdoba, Málaga e Almeria), utilizando a rota Gibraltar-Santos. De acordo com Martinez (1999), a região representada por Campinas, Sorocaba, Jundiaí, Itu, recebeu 28 mil espanhóis. O mesmo autor também informa que o Censo Nacional de 1920 registrava a presença de 2.500 imigrantes espanhóis em Sorocaba.

Esses imigrantes, em sua grande maioria, pobres e analfabetos, dedicam-se à plantação de cebolas, laranjas, batatas; abriram pequenos armazéns para o comércio de gêneros alimentícios, frutas e arreios. Instalam-se em vários pontos da cidade, mas concentram-se no Além Ponte, formando bairros como Vila Hortênsia, Barcelona, Santa Maria, Vila Haro, cujas ruas receberam denominações que se reportavam ao país de origem: Granada, Madri, Catalunha, Cervantes. A região ficou conhecida como "reduto da espanholada" e seus moradores eram principalmente operários fabris.

Os imigrantes italianos, que chegaram ao Brasil a partir de 1870, dirigiam-se em grande parte a São Paulo encaminhando-se aos centros urbanos quando tinham alguma posse de capital, ou às fazendas de café, para o trabalho braçal.

À Sorocaba também chegaram grupos representativos de italianos providos de alguma instrução e recursos, que se dedicaram à instalação de pequenas indústrias e ao comércio. Entretanto, em sua maioria, as pessoas tinham como único capital, os braços para qualquer tipo de trabalho ofertado em uma cidade que iniciava sua industrialização. 
Essa a razão de muitos terem se direcionado ao trabalho na estrada de ferro ou ao exercício de variadas atividades autônomas como costureiras, alfaiates, garçons, músicos, mascates, carroceiros. Outros, iniciaram pequenos negócios como comércio de azeite, vinho, frutas e prosperaram. A grande maioria, porém, veio compor um proletariado e como os espanhóis, se constituíram em operários nas indústrias têxteis.

Os italianos instalaram-se sobretudo no Além Linha ( referência ao bairro, próximo ao centro, "cortado" pelos trilhos da via férrea e sede das oficinas da ferrovia) e adjacências, concentrando-se nos bairros, alguns tipicamente operários, como Vila Santana e Vila Carvalho, reduto de ferroviários e trabalhadores das fábricas de fiação, tecelagem e estamparia, instaladas nas proximidades.

A imigração trouxe consigo braços fortes e ideias - essas, corpo de um projeto revolucionário, principalmente anarquista, fomentado também por intelectuais provenientes de países como a Itália, Espanha e Portugal onde o movimento libertário alcançou alguma expressão. Os trabalhadores se organizavam contra a opressão a que eram submetidos. O movimento expandiu com a criação de associações, ligas, centros operários, sindicatos, aglutinadores da militância de tendências socialistas, anarquistas, anarco-sindicalistas e marxistas, formando de acordo com Dias (1977), grupos ideologicamente contraditórios e sem coesão entre si. Os meios de manifestação na cidade eram, predominantemente dois: as greves, e a imprensa operária.

Tais movimentos, portanto, alinhavam seus pensamentos a um princípio não especificamente social, mas à crença no progresso e sua relação com o poder que, dependendo da situação, era defendida ou atacada. É por essas razões que os imigrantes, antes considerados como trabalhadores disciplinados, foram associados a uma visão simplista de marginalidade e considerados promotores de indisciplina.

Touraine (p.38) participa dessa discussão estabelecendo que ela vem agregada ao conjunto de novos preceitos e de posições de resistência, que o homem passa a adotar, juntamente com o desejo de ser sujeito de sua própria existência, " contra uma lógica cívica ou histórica que lhe parece mais como destruidora de sua liberdade e mais ainda de sua identidade". Tal disposição nascida nas sociedades industrializadas, fizeram brotar uma nova pretensão de direitos: os dos trabalhadores. O espírito das reivindicações se sustentava na consciência de necessidades ampliadas que iam das condições de trabalho, de empregabilidade e de remuneração, aos direitos culturais, educativos e das mulheres. Como ainda afirma o autor, tais movimentos começaram a por em destaque, certos fatores como justiça social e a dignidade humana.

No começo do século, são inúmeras as greves no país, como as de 1911, 1914, 1917, 1919 e outras, que se expandiram nas capitais e cidades do interior, como Sorocaba, além dos congressos operários. Neles todos constatava-se a predominância da corrente anarco-sindicalista. O desenvolvimento crescente da indústria propiciava condições para a concentração da massa operária, que passava a perceber mais claramente a exploração burguesa, constituindo organizações para defesa de seu salário e realizando manifestações, muitas vezes violentas, para garantia de seus direitos mínimos; era o desenvolvimento de uma noção mais clara, embora incipiente, sobre a oposição entre a burguesia e o proletariado.

Os operários sorocabanos participavam intensamente dos movimentos grevistas nos anos iniciais da República, pleiteando melhores condições de vida, diminuição da jornada, melhorias salariais. As reivindicações dos trabalhadores eram minimamente atendidas e, somente na medida em que representam algum interesse para o governo e o patronato. Marx e Engels (s/d) observam que como em todo movimento operário a pressão sobre a burguesia permitiu algumas conquistas, como diminuição da jornada de trabalho; mas as 
vitórias eram quase sempre passageiras, pequenas conquistas representando "triunfos efêmeros". As dificuldades enfrentadas na luta contra o Estado e o capitalismo demonstravam acima de tudo, as grandes desigualdades sociais e, infelizmente, como bem afirma Dias,(1977), "o que se conquistava hoje, perdia-se logo depois".

Para além desses movimentos, os trabalhadores ainda expressavam sua revolta contra um sistema social injusto, procurando demonstrar que eram pessoas concretas, que viviam e sonhavam na sua realidade.

Nesse contexto, o ideal republicano de instrução para o povo, de democratização e formação do cidadão, ganhou centralidade na Primeira República. A educação passou a ser considerada como condição essencial para o progresso do país, sendo defendida por vários segmentos sociais, políticos e religiosos, como grupos nacionalistas, Igreja Católica, elites urbanas. Eram óticas e interesses variados agregados por objetivos comuns no momento.

A reflexão sobre a importância da instrução, é que tempos depois levou Nagle (2001) a afirmar que sociedade deveria ser reformada, começando pela reforma do homem, tendo a escola como centro. As práticas políticas contradiziam o discurso liberal republicano, pois favoreciam os grupos que davam sustentação dos governos oligárquicos. Nas cidades as classes mais favorecidas eram contempladas com grupos escolares, muitas vezes luxuosos, enquanto a maioria da população continuava analfabeta.

Entre os excluídos estavam os operários que, para além das reivindicações trabalhistas, passaram a requerer educação para seus filhos. Como alternativa, para eles, os militantes criavam escolas não institucionalizadas, com propostas pedagógicas anarquistas inspiradas na Escola Moderna de Barcelona, concebida por Francesc Ferrer i Guàrdia, educador e militante catalão. Os modelo pedagógico dessas escolas objetivam a educação racional da criança, livre das influências perniciosas da religião, da burguesia e do governo.

Braço forte dos movimentos sociais nesse momento foi a imprensa operária. Em Sorocaba, o Jornal O Operário que circulou de 1909 a 1913, se identificou como uma das expressões da intervenção político-administrativa dos trabalhadores no âmbito da história sorocabana propiciando inclusive, espaço de expressão para algumas articulistas femininas. Inicialmente de orientação socialista, com o tempo o jornal passou a seguir, de maneira declarada, uma linha anarquista.

Seus redatores eram unânimes no ataque à burguesia, ao governo, ao clero. A contrapartida se caracterizava pela defesa do direito à educação do operário, caminhando em direção oposta ao conservadorismo dos grupos hegemônicos da cidade. A pesquisa dos acervos da imprensa nos permitiu desvelar dimensões não presentes nos documentos oficiais como por exemplo, a divulgação das teorias de Ferrer e o pensamento feminista.

Nas páginas do $O$ Operário constatava-se a presença constante de Ferrer em artigos políticos e sobre educação, além de argumentos que o levaram a exercer grande influência na fundação da escola racional de Sorocaba. Desde as primeiras edições do jornal pôde ser verificada a realização de palestras por líderes anarquistas italianos radicados no Brasil, que aportavam à cidade procurando incentivar os operários à adoção do ensino racional, livre da influência religiosa e burguesa. De acordo com as evidências encontradas, Ferrer tornou-se um personagem emblemático para o jornal, memória oportunamente preservada junto aos operários

Analisando as concepções educacionais de Ferrer percebe-se a incorporação do objetivo da instrução integral, e a indissociabilidade entre formação intelectual e prática, advindas de Bakunin. Do Comitê de Iniciativa para o Ensino Integral (1898), Ferrer assimilou os ideais do ensino intelectual e profissional, o ensino racional, libertário e 
misto. A coeducação sexual e entre as classes, eram entendidas como favorecedoras do relacionamento e do desenvolvimento fraternal entre as crianças, evitando assim preconceitos e privilégios.

Diferindo das escolas tradicionais, as racionais não adotavam exames, castigos e prêmios, estes, para não haver competição e estímulo à vaidade. Para o educador, o mais importante era o respeito e a atenção à aptidão individual de cada criança. Para que tal educação fosse viável, os professores deveriam ser preparados e livres dos vícios do ensino tradicional. Além disso, os mestres deveriam ser constantemente atualizados em seus conhecimentos para acompanhar o desenvolvimento das crianças.

Ao lado das reivindicações sobre criação de escolas e diminuição da jornada de trabalho infantil, o jornal $O$ Operário constituía um universo à parte enquanto preocupação com a educação da criança operária, procurando prepará-la para o combate à burguesia, valorização da liberdade, da democracia e da justiça, e, também enquanto defesa de ideais singulares ao pensar educação no âmbito de um desenvolvimento expandido para além dos bancos escolares: um entendimento mais próximo do conceito aristotélico de "ação humana em sociedade", como já apresentado.

O grupo anarquista do jornal defendia a implantação da escola moderna, com bases racionais, inspirada principalmente na Escola Moderna de Barcelona, criada por Francesc Ferrer i Guàrdia. A implantação da escola contou com a colaboração de líderes anarquistas provenientes de São Paulo, como Oreste Ristori ${ }^{3}$ que, em visita a Sorocaba se pronunciou publicamente:

sobre vários pontos referentes à escola moderna, demonstrando de um modo claro e preciso as vantagens do ensinamento único racional, o único verdadeiro, o único digno de ser ministrado aos nossos filhos, para que não sejam amigos de padres e de ... confessionários. ( $O$ Operário, 24/ 04/1910, p. 2).

A Liga Operária de Sorocaba foi responsável pela criação de uma escola noturna para adultos e crianças operárias, tendo como professor e administrador, Joseph Jubert Revier, imigrante francês e sindicalista ativo, também colaborador do jornal. A escola funcionou nos anos de 1911-1912. O professor, para além de escrever e contar, procurava incutir em seus alunos os princípios anarquistas, a conscientização política, o anticlericalismo, os ideais de liberdade e emancipação da mulher e de todos os trabalhadores.

Tragtenberg (1978) afirma que o pensador espanhol reconhecia que o interesse do Estado pela educação das massas, era justificado pelo modo capitalista de produção, para quem operários alfabetizados eram necessários não só para o trabalho com as máquinas mas também para o aumento de rendimentos. Entretanto, os governos ofereciam um ensino com objetivos de manutenção dos valores sociais vigentes e não de sua transformação; esses valores asseguravam seu poder, domínio. Para isso, a escola deveria continuar a ser dominada pelo Estado e servir a seus propósitos.

Vinha daí, pois, a razão pela qual se idealizava uma transformação social, uma revolução iniciada pela escola, pela educação. Por isso Ferrer pensava a educação da classe trabalhadora em um ambiente racional, laico e não coercitivo, capaz de instruir na justiça, na verdade, na capacidade de raciocinar e de eliminar preconceitos. Razão pela qual identificava educação como questão política, sedimentada em posições e práticas pedagógicas anti-autoritárias.

A proposta educativa de Ferrer tinha por pressupostos o racionalismo pedagógico, tendo como foco o ensino das ciências naturais, o laicismo, o afastamento do ensino 
religioso, a liberdade, a igualdade, a educação integral (trabalho intelectual e manual), a co-educação dos sexos e das classes, entre outros.

Exemplificando:

[...] em la Escuela Moderna tendrán representación proporcionada todos los conocimientos de carácter cientifico, servidos por los más progresivos métodos que hoy conoce la Pedagogia, así como por los instrumentos y aparatos que son lãs alas de la ciência y el médio conductor más potente para obrar em la inteligência de los educandos (FERRER i GUARDIA, 2009, p. 83).

De maneira muito específica, a imagem da mulher inscrevia-se no panorama social brasileiro, com poucas modificações substanciais. De herança portuguesa, vinha uma educação articulada à evangelização católica - o princípio do bem comum estava tão forte e presente no ideário do cristianismo católico, que não gerava responsabilidade quanto à vivência histórica. Tal mentalidade era particularmente sentida quando o alvo de reflexão se referia, mais precisamente, à função social de esposa/dona de casa fundamentada desde os primórdios como a mais alta expressão de feminilidade, não só baseada no discurso da Igreja, como plenamente ratificada pelas várias instâncias sociais: o direito, a área médica, a ação do Poder Público, os meios de comunicação.

A respeito, D' Incao (2001) expõe as características dessas representações sobre a vida da mulher. Dela era esperado manter um sólido ambiente, lar acolhedor, filhos educados; a esposa desobrigada de qualquer trabalho produtivo e dedicada ao marido e às crianças, apresentava-se como modelo de probidade, retidão de caráter, um tesouro imprescindível do qual a sociedade não abria mão.

Para os positivistas, a família era a base da sociedade e a mulher sua sustentação. Hanher (apud Silva 2002) afirma que dos sentimentos da mulher e de seu instinto maternal, dependiam "a educação das crianças e a formação e modificação do homem adulto (...) sua função de mãe de família, de filha, de irmã, de esposa". As relações familiares estavam identificadas como responsabilidade exclusivamente feminina.

Mesmo assim, as necessidades do cotidiano das cidades, levaram a mulher a adentrar ao mercado de trabalho. Sua labuta diária se distribuía em múltiplas atividades: negociantes, verdureiras, lavadeiras, cozinheiras, costureiras. O trabalho a domicílio tinha a preferência apesar dos parcos ganhos, e, da exploração das patroas e freguesas pois, de alguma maneira, permitia-lhe continuar respondendo pelos compromissos da própria casa.

Paralelamente aos serviços da casa, algumas mulheres foram ocupando aos poucos, também, os espaços da fábrica. Fiandeiras, urdideiras, tecelãs... trabalhadoras incansáveis, com longas jornadas (menores porém que nos trabalhos domésticos e domiciliares) e salários melhores dos obtidos na prestação de serviços, mesmo sendo irrisórios. Isso deu às mulheres certa visibilidade no mercado no contexto da produção, permitindo que demonstrassem competência, potencialidade e até liderança. Entretanto, também para elas, nenhuma dessas características significou uma abdicação das tarefas do cotidiano doméstico. Mas, participar das frentes produtivas no interior das fábricas, possibilitou, lentamente, que tivessem a condição feminina pensada e manifestada por alguns segmentos da imprensa e pelos movimentos sociais.

Também nesse aspecto, os princípios da Escola Moderna do pensador catalão Francesc Ferrer y Guardia se distanciavam dos educadores tradicionais ao valorizar a mulher, incentivando-a a estudar, a não se limitar aos serviços caseiros. Seus estudos, quanto aos ensinamentos científicos, deveriam ser iguais aos dos homens (FERRER, apud TRAGTENBERG, 1978). A teoria de Ferrer reflete de modo muito especial suas 
preocupações com a condição feminina, particularmente no que se refere ao acesso à educação.

O jornal $O$ Operário procurava servir também como instrumento de educação e conscientização das mulheres, na dimensão do papel a assumir na sociedade que estava sendo construída, e que se mostrava sob novas perspectivas sociopolíticas e culturais.

No processo de industrialização e da urbanização, ocorreram também transformações nos hábitos sociais e familiares, principalmente das classes trabalhadoras. Diversamente da família burguesa, na família das classes populares, as mulheres trabalhavam em dupla jornada: cumpriam todos os afazeres domésticos e produziam para o mercado de trabalho como operárias nas fábricas, entre outras atividades. Trabalham entre 12 e 14 horas diárias, com ínfimos salários, e assumiam a responsabilidade pela educação dos filhos, considerada "assunto de mulher" e de sua total responsabilidade.

Em sua grande maioria constituída de analfabetas, a população feminina sofria de todas as restrições de uma ordem social discriminatória e enfrentava a precariedade imposta pela condição financeira. Aos poucos, dessa realidade, começou a emergir uma mulher que inicialmente de forma tímida, foi abandonando a atitude passiva e passou a agir contra a ordem econômico-social vigente. Participando do movimento operário, exigindo melhores condições de vida, educação e, muitas vezes, escrevendo nos jornais operários, o comportamento dessas mulheres veio por esclarecer e incentivar as mulheres a aderir e colaborar com as transformações daquele momento histórico. Em Sorocaba, as mulheres tiveram certo destaque participando da Liga Operária, sendo bastante atuantes nas greves e participando, também, como articulistas do jornal. Uma das mais presentes é Elvira, que escrevia sobre vários assuntos e aparece como uma das mais ferrenhas defensoras do livre pensamento.

Exemplo de veemência verbal e do posicionamento da autora, o artigo "O Divórcio", escrito por Elvira, posicionava-se pela não aceitação dos princípios da Igreja Católica

Anda por toda a parte a carolada que cheira a sebo da Sacristia,
protestando contra a lei do divórcio..[...] Parece incrivel que essa
jesuitada de casaca e outros tantos de batina se preocupem tanto com a
resolução que tomaram meia dúzia de homens de repellir os
preconceitos da infernal Madre Igreja. Não contentes essa corja de
destruírem o amor livre e levantarem códigos para o affecto e
legislações para o poema do beijo, criando leis para a união passional
de duas almas complementares que se encontraram e se amaram nos
embates da luta $(O$ Operário, $27 / 10 / 1912$, p. 2$)$.

$\mathrm{O}$ artigo continua, defendendo o amor livre, o direito da mulher de escolher seu companheiro sem a imposição da família. Os desafios às normas instituídas pelo catolicismo demonstram uma aproximação com as tendências ideológicas socialistas e anarquistas, muito em evidência naquele momento.

Para além da oposição à igreja, o artigo acima demonstra um posicionamento em defesa da mulher, no mínimo contrastante com os costumes, valores morais e religiosos arraigados na sociedade do início da República. Além disso, por ser escrito por uma mulher, abria espaço para participação feminina na imprensa sorocabana, território notadamente reservado aos homens.

Em contraposição ao conservadorismo masculino (e, também, feminino) Elvira representava novas aragens. Os diversos textos publicados, com o devido destaque, contemplavam vários assuntos, como política, funcionamento da Câmara Municipal, ensino superior. Sugerem que a autora tenha sido uma pessoa bastante combativa, 
participante e com afinidades políticas e ideológicas em relação aos redatores do jornal, em sua fase notadamente anarquista.

No texto "A Burguesa e a Anarchista", Elvira criticava a mulher burguesa, que não tinha consciência da maternidade, encarando-a como "acidente"; a burguesa educava os filhos como foi educada, ou seja, para a hipocrisia, para a injustiça, para a exploração dos mais pobres. Em contraposição,

A verdadeira mãe, a mãe ideal, diferente destes tipos, prepara os seus filhos ao trabalho, ensina-lhe o sacrifício. Esta é a verdadeira anarchista.......] Uma mãe anarchica não escolherá para sua filha um marido usurpador e perverso ...não ambiciona para seus filhos e seu companheiro, cargas de cruzes, diplomas e galões que dão o direito de explorar o trabalho dos outros. [...] A verdadeira mãe! Oh, sublime realidade das gerações futuras, este tipo de mãe anarchica é o sonho de todos os corações bons, a luz da humanidade nova, fundada sobre as bases do trabalho e do amor. Na mulher anarchica está pois a salvação do mundo (O Operário, 12/03/1913, p. 1).

A mulher e a mãe ideais seriam, pois, as mulheres anarquistas, que teriam consciência da missão social de educar os filhos e, incentivar os companheiros para a formação de uma sociedade futura mais justa. A autora, embora defendendo o amor e a paixão como condições para escolha dos companheiros, fato que caminhava na contramão dos bons costumes da época, aceitava e enaltecia o papel da mulher enquanto mãe, também reconhecido pela sociedade burguesa e pela religião. Entretanto, sua concepção de mulher/mãe como formadora de uma nova humanidade a diferenciava da concepção burguesa e a aproximava da ideologia anarquista.

Talvez, a mais revolucionária, contestadora dos preceitos religiosos e da moral burguesa, além de consciente dos problemas sociais, tenha sido Joana Dubois, no artigo "Greve dos Ventres", publicado em duas partes, pelo O Operário, nos dias 20/01 e 06/02/1910.

Concordando que os oprimidos tinham apenas sua força para vencer o capitalismo, a autora elencava as condições necessárias para a verdadeira emancipação: aumento de salário, redução da jornada de trabalho, que poderiam ser obtidos por meio de greves; entretanto considera essencial a "greve dos ventres", que significava "tanto ter poucos filhos como não ter nenhum”, pois

Os encargos familiares excessivos impedem que muitos explorados se façam revolucionários [...] então o trabalhador não tem tempo e recursos para tomar consciência dos seus direitos pela leitura, discussão e nas reuniões públicas [...] a mãi, sempre metida em casa, não reflete e não pode abandonar suas ideias cobardes, mesquinhas e obriga com suas lágrimas ou censuras o marido ou o amante a calar as suas opiniões e a renunciar à revolta.

Joana justificava o medo do homem e da mulher de se exporem quando têm muitos filhos a sustentar e afirma:

Não nos parece, pois errôneo, dizer que a dominação de nascimentos, efeito do pauperismo por um lado, pode, por outro lado aumentar a velocidade do movimento revolucionário [...] numerosas demais as crianças não deixam que os genitores se preparem e as preparem para realizar a transformação social. 
No preparo da criança estava incluída a educação integral, que certamente seria prejudicada pelo excesso de demanda, fato que repercutiria na evolução do movimento revolucionário. De acordo com Joana, do ponto de vista social era importante a limitação consciente da natalidade, para que as crianças fossem educadas para respeitar a liberdade dos "outros no trabalho, no amor, na procriação", para formar seres "capazes de compreender a felicidade alheia, sabendo medir o alcance doa actos próprios sobre a sociedade".

A autora ainda afirmava: "Não me limito a reivindicar a livre maternidade; considero a fecundidade natural como um dos perigos sociais e não à maneira de Malthus como o perigo social", concluindo que "em qualquer época [...] as condições de procriação e as condições do trabalho parecem-me ser da mesma importância". O artigo demonstrava seu posicionamento a favor do direito da mulher de usar seu corpo de acordo com seus desejos, da utilização de métodos contraceptivos e da desvinculação entre sexo e procriação.

Entretanto, para além desses pressupostos sobre os direitos femininos, Joana manifestava sua compreensão sobre a relação existente entre a procriação não controlada e os problemas sócio-políticos por ela acarretados. Tinha a percepção da importância do controle da natalidade como estratégia revolucionária.

De maneira geral, as representantes femininas no jornal demonstravam certa cultura e adotavam uma posição progressista, defendendo seus direitos de liberdade, igualdade diante dos homens e contrárias aos preceitos determinados pela Igreja Católica, num movimento que se traduzia no anticlericalismo, característica da corrente anarquista do jornal.

O jornal preocupava-se com a educação formal das meninas e operárias adultas, lutando para que freqüentassem escolas tradicionais ou racionais, bem como da educação informal, por meio dos artigos do jornal.

A educação feminina identificava-se assim sob novos preceitos sendo apresentada por incisivos pontos de divergência com os modelos praticados, por exemplo, no contexto da casa, do trabalho e pela adoção de novas características de comportamento pessoal e sociais.

A nova visão das condições femininas ficava evidenciada tanto na educação formal (direitos de presença da mulher escolarização para meninas e operárias) como na informal, expressando-se nos artigos e aconselhamentos que objetivavam educar a "nova mulher" no novo momento histórico: conciliar os afazeres domésticos com o trabalho têxtil e a produção industrial. Nesse sentido, combatia a moral burguesa por ser ela opressora da mulher em todos os sentidos e independente da condição social, sendo particularmente perversa com a mulher que trabalhava fora de casa.

Para melhor entender a extensão dessas preocupações e o impacto dos argumentos e posições, se faz oportuno dimensionar o que caracterizava a educação feminina no período. Pelo ideário convencional ela não poderia ser concebida sem uma sólida formação cristã - chave de qualquer projeto educativo. No entendimento de Nunes (2001): "Esperava-se que as meninas e jovens construíssem suas vidas pelo legado mariano e seu apelo pela socialização da pureza, da maternidade, da perfeição moral, aceitação de sacrifícios pelo bem da família e dos filhos". Atuando como ratificador dessa realidade, cumpre citar o princípio expresso pela $1^{\text {a }}$ Lei de Instrução Pública do Brasil, de 1827 , que assim se pronunciava:

As mulheres carecem tanto de mais instrução, portanto são elas que dão a primeira educação aos filhos. São elas que fazem os homens bons e maus; são as origens das grandes desordens,como dos grandes bens; os homens moldam sua conduta aos sentimentos delas. 
Em contraposição, a teoria de Ferrer, cabe como entendimento de um novo arcabouço teórico que abandonava os propalados "imperativos de gênero" como determinadores dos papéis e representações sociais. Fiel aos ideais racionais, o educador estende a educação feminina para o universo dos direitos e da cidadania ativa. Um dos princípios fundantes, da teoria de Ferrer o da coeducação, justificava-se no argumento pelo qual as humanidades feminina e masculina deveriam ser complementares desde a infância, cabendo à mulher não ser do homem, mas sua companheira.

A defesa da educação feminina foi a principal bandeira de luta para a emancipação da mulher. Visava, também, aperfeiçoar o papel da mãe como educadora, porém, de uma mãe instruída, moderna, em oposição à figura da mulher ociosa, ignorante, submissa e alheia ao mundo, ou seja, uma figura feminina que tivesse uma maior projeção em todos os âmbitos da vida social. Com o pensamento de Ferrer o texto encerra suas reflexões afirmando

\begin{abstract}
Se ha dicho [...] La mujer es la continuidad y el hombre es el cambio; el hombre es el individuo y la mujer es la especie. Pero el cambio, la mutación en la vida no se comprendería, sería un parecer fugaz, inconsistente, desprovisto de realidad, si no se tuviera al obrero femenino que afirmara y consolidara lo que el hombre produce. El individuo, representado por el varón, como tal individuo, es flor de un día, de efímera significación en la sociedad. La mujer, que representa la especie es la que posee la misión de retener, en la misma especie, los elementos que le mejoren la vida, y esos elementos, para ser adecuamente sabidos, es preciso tener de ellos conocimientos científicos (FERRER i GUARDIA, 2009, p. 94).
\end{abstract}

\title{
Referências
}

ARISTÓTELES Coleção Os Pensadores, Abril Cultural, São Paulo., SP., 1973.

BOSCHETTI, Vania Regina e FERREIRA, Valdelice Borghi. Discursos educacionais na imprensa: algumas leituras, Anais Eletrônicos do VII Congresso Luso-Brasileiro de História da Educação, Universidade do Porto, Porto, Portugal, 2008.

DIAS, Everardo História das lutas sociais no Brasil, Alfa Omega, São Paulo, SP. 1977

D'INCAO, Maria Ângela. Mulher e família burguesa, in DEL PRIORE, Mary.(org.) "História das Mulheres no Brasil", Contexto, São Paulo, SP. 2001

FERREIRA, Valdelice Borghi. O movimento operário e a educação na imprensa sorocabana na Primeira República. Tese (Doutorado em Educação) - Programa de PósGraduação em Educação, Universidade Metodista de Piracicaba, Piracicaba, SP. 2009

FERRER GUARDIA, Francisco. La Escuela Moderna. Barcelona, Espanha: Tusquets Editora, S.A, 2009.

MARX, Karl e ENGELs, Frederich, Manifesto do Partido Comunista, in "Obras Escolhidas", vol.1, Alfa-Omega, São Paulo, SP. (s/d)

MARTINEZ, Elda Evangelina Gonzále. O Brasil como País de Destino para os Migrantes Espanhóis, in FAUSTO, Boris (org), "Fazer a América”, Edusp, São Paulo, SP. 1999

MATOS, Maria Izilda Santos. Cotidiano \& Cultura: história, cidade e trabalho, Edusc Bauru, SP. 2002 
NAGLE Jorge, Educação e Sociedade na primeira República, DP\&A Editora, Rio de Janeiro, RJ. 2001

NUNES, Maria José Rosado. Mulher e família burguesa, in DEL PRIORE, Mary.(org.), "História das Mulheres no Brasil", Contexto, São Paulo, SP. 2001

OLIVEIRA, Sergio C. Os Espanhóis, TCM/Linc, Sorocaba, SP. 2002

O Operário, Edições de 1909 a 1913, Gabinete de Leitura Sorocabano, Sorocaba, SP.

PINTO, L. Costa. O negro no Rio de Janeiro: relações de raças numa sociedade em mudança. UFRJ, Rio de Janeiro, RJ. 1998

SAFÓN, Ramón. O racionalismo combatente: Francisco Ferrer Y Guardia, Editora Imaginário, São Paulo, SP. 2003

Silva, Erineuza Maria da. As relações de Gênero no Magistério: a imagem da feminização. Edufes, Vitóri, ES. 1968

TRATGTENBERG, Mauricio. Francisco Ferrer e a pedagogia libertária, Educação e Sociedade, nº 01, Cortez/Autores Associados, São Paulo, SP. 1998

TOURAINE, Alain. Igualdade e Diversidade: o sujeito democrático,. Edusc, Bauru, SP. 1998

www.facef.br - "Anarquismo e feminismo: as mulheres anarquistas em São Paulo na $1^{a}$ República - acesso em 25 março 2010.

www.diaadiaeducacao.pr.gov.br - acesso em 25 março 2010.

\footnotetext{
* Doutora em Geografia Humana pela USP. Professora titular do Programa de Pós-Graduação em Educação da Universidade de Sorocaba. E-mail: vania.boschetti@prof.uniso.br.

** Doutora em Educação Pela Universidade Metodista de Piracicaba. Coordenadora do Curso de Pedagogia da Universidade de Sorocaba. E-mail: valdelice.ferreira @ prof.uniso.br

${ }^{1}$ Para os intérpretes de Aristóteles o "zoon politikon" não deve ser compreendido como "animal socialis" da tradução latina. Este desvio semântico resultou num sentido alargado do termo grego que acabou se identificando com o social. Para Aristóteles, o social significava mais o instinto gregário, algo que os homens compartilham com algumas espécies de animais. O simples viver junto, em sociedade, não caracteriza a destinação última do homem: a "politicidade". A verdadeira vida humana deve almejar a organização política, que é uma forma superior e até oposta à simples vida do convívio social da casa (oikia) ou de comunidades mais complexas. A partir da compreensão da natureza do homem determinados aspectos da vida social adquirem um estatuto eminentemente político, tais como: a noção de governo, de dominação, de liberdade, de igualdade, do que é comum, do que é próprio etc. Prof. Dr. César Augusto Ramos. www.unicamp.br/cemarx/cesar.htm.

${ }^{2}$ De acordo com Touraine (1998), são quatro as idéias principais que definem o modelo clássico de sociedade: a) a ordem social é produzida, criada e não transmitida ou submetida a uma ordem superior, o que implica a ruptura com a ordem religiosa; b) a sociedade e o seu interesse tornam-se o próprio princípio de avaliação moral do comportamento. O bem e o mal não são definidos por tradição ou por divindade; c) a sociedade produz seres semelhantes mais desiguais; d) o apelo à igualdade contra a desigualdade tem força histórica porque fundado sobre uma confiança absoluta e uma evolução histórica natural.

${ }^{3}$ Oreste Ristori: agitador anarquista italiano; fundou o jornal La Bataglia, em São Paulo. Foi expulso do Brasil duas vezes, sendo a última em 1936. Escreveu na Itália, folhetos contra o tratamento dado aos imigrantes no Brasil. Morreu na Espanha, em 1937, lutando contra as tropas de Franco.
} 